\title{
Defining ductal tissue
}

\author{
Ming-Sing Si, MD
}

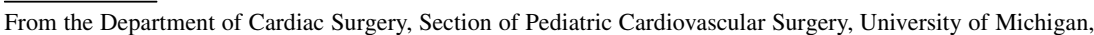 \\ Ann Arbor, Mich. \\ Disclosures: Author has nothing to disclose with regard to commercial support. \\ Received for publication July 14, 2016; accepted for publication July 18, 2016; available ahead of print Aug 17, \\ 2016. \\ Address for reprints: Ming-Sing Si, MD, 11-735 C.S. Mott Children's Hospital SPC 4204, 1540 E. Hospital Drive, \\ Ann Arbor, MI 48109-4204 (E-mail: mingsing@umich.edu). \\ J Thorac Cardiovasc Surg 2016;152:1457-8 \\ $0022-5223 / \$ 36.00$ \\ Copyright (C) 2016 by The American Association for Thoracic Surgery \\ http://dx.doi.org/10.1016/j.jtcvs.2016.07.043
}

Aortic coarctation occurs from involution of ductal tissue, which causes a decrease in luminal cross-sectional area. Standard repair of aortic coarctation entails the removal of this ductal tissue and anastomosis of the free ends of normal aortic tissue. The removal of ductal tissue depends on recognition of the pulpy and soft macroscopic characteristics noted by the surgeon. The extent of ductal tissue resection also is inherently limited; indiscriminate and extensive resection of ductal tissue with unnecessary large margins of normal tissue would leave a large gap and tension in the anastomosis with left bronchial compression.

Recurrence of coarctation after repair is thought to be secondary to remnant/residual ductal tissue present at the anastomosis. Recurrent coarctation in neonates and infants who have undergone repair occurs with a rate of $6 \%$ $10 \% .^{1-3}$ Although most of these can be addressed successfully with balloon angioplasty, this type of reintervention is not free of risk. ${ }^{4}$

Thus, an approach to mitigate recurrent coarctation is to first identify and then completely remove all ductal tissue while preserving normal aortic tissue. In this issue of the Journal, Iwaki and colleagues ${ }^{5}$ present a proof-of-concept study of using synchotron radiation-based $\mathrm{x}$-ray phase contrast tomography (XPCT) to image ductal tissue in 2 coarctectomy specimens. Although this was an ex vivo imaging study of these specimens, it reliably demonstrated the presence of ductal media and intima as well as normal aortic tissue. These XPCT results were confirmed with histologic studies. In this pilot XPCT study, these investigators found that ductal intima was present more distally and laterally than the ductal media, especially on the inner curvature. The authors suggest that resection of this region may prevent recoarctation.

The major weakness of this study stems from its small sample size, and thus any generalizations about the presence of ductal intima and media must be taken with a grain of salt. Another consideration, as the authors mention, is the clinical applicability of this imaging technology. Currently, such technology does not exist for clinical use, primarily because current x-ray sources are too

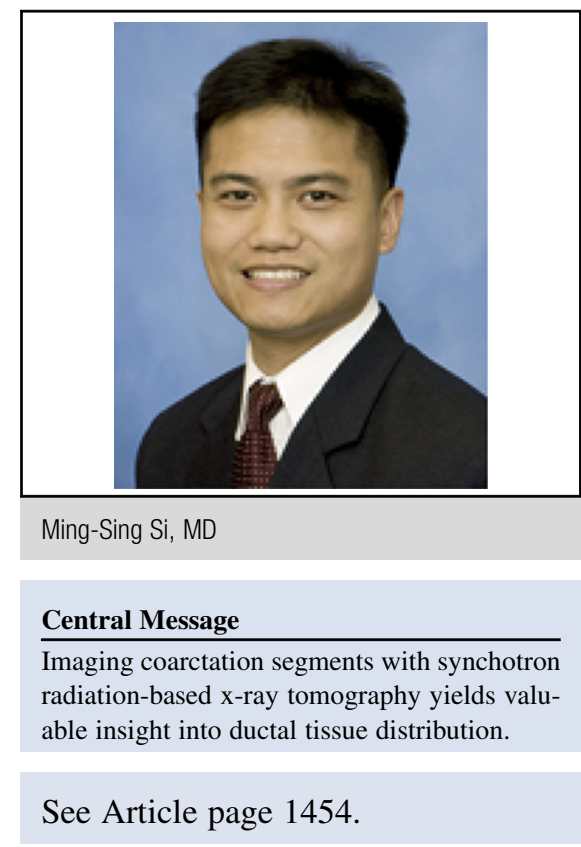

large and data acquisition is too slow, especially for the pulsatile aorta in vivo; however, these are areas undergoing rapid progress and perhaps will become available in the foreseeable future.

The ability to create a high-resolution, 3-dimensional map of ductal intima and media in resected coarctation segments is the major strength of this study. Although synchotron radiation-based XPCT won't be seeing clinical application yet, using this technology to study resected coarctation segments and provide a rigorous 3-dimensional map of ductal intima and media (ie, expanding upon this pilot study) would be potentially useful to clinicians and would complement the comprehensive histologic study of aortic coarctation by $\mathrm{Ho}$ and Anderson ${ }^{7}$ nearly 4 decades ago.

Imaging ductal tissue to guide resection during coarctation repair is an important concept that currently remains theoretical. Obtaining fast, high-resolution imaging of the pulsatile aorta to identify ductal tissue in the neonate or infant represents a formidable technological challenge. Perhaps an intermediate advance of epivascular imaging of the clamped (ergo nonpulsatile) aorta just before resection would be more feasible. Such an effort would be ideally driven by the surgeon-investigator.

\section{References}

1. Wright GE, Nowak CA, Goldberg CS, Ohye RG, Bove EL, Rocchini AP. Extended resection and end-to-end anastomosis for aortic coarctation in infants: results of a tailored surgical approach. Ann Thorac Surg. 2005;80:1453-9. 
2. McGuinness JG, Elhassan Y, Lee SY, Nolke L, Oslizlok P, Walsh K, et al. Do highrisk infants have a poorer outcome from primary repair of coarctation? Analysis of 192 infants over 20 years. Ann Thorac Surg. 2010;90:2023-7.

3. Burch PT, Cowley CG, Holubkov R, Null D, Lambert LM, Kouretas PC, et al. Coarctation repair in neonates and young infants: is small size or low weight still a risk factor? J Thorac Cardiovasc Surg. 2009;138:547-52.

4. Saxena A. Recurrent coarctation: interventional techniques and results. World $J$ Pediatr Congenit Heart Surg. 2015;6:257-65.
5. Iwaki R, Matsuhisa H, Hoshino M, Oshima Y. Three-dimensional evaluation of ductal tissue in coarctation of the aorta using X-ray phase-contrast tomography. J Thorac Cardiovasc Surg. 2016;152:1454-6.

6. Zhao Y, Brun E, Coan P, Huang Z, Sztrókay A, Diemoz PC, et al. High-resolution, low-dose phase contrast X-ray tomography for 3D diagnosis of human breast cancers. Proc Natl Acad Sci U S A. 2012;109:18290-4.

7. Ho SY, Anderson RH. Coarctation, tubular hypoplasia, and the ductus arteriosus. Histological study of 35 specimens. Br Heart J. 1979;41:268-74. 